$\xi=\mathrm{\alpha}$

\title{
Treatment of nylon garment to improve its properties
}

\author{
Ghada Abdalla Lotfy Elkholy* \\ Apparel Design and Technology Dept.Faculty of Applied Arts, Helwan University, Cairo, Egypt \\ *Corresponding author E-mail: ghada_elkholy@hotmail.com
}

\begin{abstract}
Nanotechnology is extensively used in textile industries because it confers unique properties on fabrics.In this study, using nano silicon dioxide ( $\mathrm{SiO} 2$ )-coated nylon fabrics have created a lot of awareness appropriate to improve their functional properties. Using deferent construction of nano silicon dioxide ( $\mathrm{SiO} 2)$, the optimization construction are used to carry out treatments impart to improve the roughness, antistatic charge, sew ability, thickness; weight and UPF measurement are investigated. The study evaluates the possibility of using the scanning electron microscope (SEM) to show optimize the effect of treatment of nylon fabrics with nano silicon dioxide not only on the effect of treatment of nylon fabrics with nano silicon dioxide not only on their performance and appearance but also in garment manufacturing.
\end{abstract}

Keywords: Nylon Fabrics; Mechanical Properties; UPF; Sewability and SEM.

\section{Introduction}

Nanotechnology is extensively used in textile industries because it confers unique properties on fabrics such as ultraviolet (UV) protection, antibacterial activity, fire resistance, and high durability [1]. The large surface-to-volume ratio of the nano particles is effectively interacted with fabric surface due to the Van der Waals forces involved in both [2]. The inorganic materials like metals and metal oxide-coated fabrics have created a lot of awareness appropriate to improve their functional properties [3]. Owing to their cost consideration, a small amount of metal nanoparticles,compared with the usage of metal oxide nanoparticles, are used in textile industry. The metal oxide nanoparticles, like $\mathrm{Al} 2 \mathrm{O} 3$, $\mathrm{SiO} 2, \mathrm{MgO}, \mathrm{ZnO}, \mathrm{TiO}_{2}$ [4], etc., The alteration of materials' surface properties by nano size $\mathrm{SiO}_{2}$ particles improves the mechanical properties and durability of materials and also influences material's functionality, activity or can enhance its stability.[5,6] Microbiological tests were carried out on these textiles and confirmed their good antimicrobial activity. The role of silica spheres in $\mathrm{SiO}_{2} / \mathrm{Ag}$ is as $\mathrm{Ag}$ metal carriers and effective matrix causing good dispersion of silver nanoparticles in polymer matrix. [7], [8]Treatments with different softeners on nylon fabrics enhancement anti pilling.[9]In the synthetic component provides crease recovery, dimensional stability, tensile strength, abrasion, resistance and easy care properties, but low in moisture absorption, antistatic characteristics and reduced pilling. [10] Some fabrics particularly synthetics such as polyester and nylon - tend to gather static charge. Whisk a top over your head and your hair stands on end. But nanoparticles that conduct electricity, such as zinc oxide, titanium dioxide and antimony-doped tin oxide, can help disperse this charge.

At the moment, clothes featuring nanotechnology are largely made from standard fabrics upon which a nano-coating has been applied. But in the future we're likely to see more fabrics made from nanofibres, with nanoparticles and nanofilaments an integral part of the weave. A new era of "smart" fabrics, for example, could automatically respond to your body and the environment around you. [11], [12]

A high penetration force means a high resistance of fabric. Sewing needle penetration force is one of the most significant technical parameters in the sewing process which affected by various factors such as type of layers of the sewing material, needle size, needle point shape, speed of the sewing machine, fabric design, finish of fabric, type of sewing machine used, stitching conditions and the behavior of the sewing thread.. The sewing needle penetration force is the quantitative measure of the damage which appears in agreement as the result of the sewing process [13], [14], [15] [16], [17], [18]

In this study, surface treatments of nylon knitted fabrics with using nano silicon dioxide $\left(\mathrm{SiO}_{2}\right)$ are carried out to improve some of their mechanical properties such as antistatic charge, roughness, weight,sewability, thickness surface and UPF. The obtained results will surely help to identify the design criteria for clothing so as to produce high quality garments.

\section{Experimental}

\subsection{Materials}

Nylon 6.6 weft knitted fabrics were supplied by jockey Co Cairo, Egypt, for Spinning, knitting and dyeing . The fabrics were soaped with $(2 \mathrm{~g} / \mathrm{L})$ nonionic detergent solution (Hostapal C .V., from Clariant $\mathrm{Co}$, Egypt) with a liquor ratio $1: 25$, at $45^{\circ} \mathrm{C}$, for $30 \mathrm{~min}$, then rinsed twice in cold tap water, and dried at room temperature. Show Table 1.

Table 1: Show Specifications of Samples.

\begin{tabular}{|c|c|c|}
\hline Samples & Nylon & Nylon \\
\hline Fabric types & Weft knitted & Weft knitted \\
\hline Composition & $100 \%$ & $100 \%$ \\
\hline Yarn number & $96 \backslash 60$ denier & $80 \backslash 60$ denier \\
\hline Construction & Single jersey & Single jersey \\
\hline Density & $\begin{array}{c}\text { courseslcm } \\
14\end{array}$ & $\begin{array}{c}\text { courseslcm } \\
13\end{array}$ \\
\hline
\end{tabular}

Copyright $\odot 2017$ Ghada Abdalla Lotfy Elkholy. This is an open access article distributed under the Creative Commons Attribution License, which permits unrestricted use, distribution, and reproduction in any medium, provided the original work is properly cited. 


\subsection{Chemical}

The nanoparticle used in this study is $\mathrm{SiO} 2$, obtained from Sigma - Aldrich, Germany. Potassium hydroxide and Methyl alcohol are of laboratory grade.

\subsection{Alkaline pretreatment of nylon}

To improve the adhesion of $\mathrm{SiO}_{2}$ nanoparticle to the smooth surface of nylon fabric, an alkaline pretreatment in water solution containing $5 \mathrm{~g} / \mathrm{L}$ of $\mathrm{KOH}$ for $30 \mathrm{~min}$ at $98^{\circ} \mathrm{C}$ with a liquor ratio 1: 25 was performed. Subsequently, the samples were rinsed twice in cold tap water and then dried at room temperature.

\subsection{Treatment}

The nylon fabrics were immersed in solutions of $(5 \mathrm{~g} / \mathrm{l})$ and $(10 \mathrm{~g} / \mathrm{l})$ $\mathrm{SiO}_{2}$ nanoparticle with a liquor ratio 1: 10 (ethanol: water) for $1 \mathrm{hr}$. at room temperature. The fabrics were then padded at $100 \%$ pick up using a laboratory padding machine. One series of the padded samples are cured at $80^{\circ} \mathrm{C}$ for $5 \mathrm{~min}$. The samples were rinsed with cold water then rinsed with tap water, and finally air dried.

\subsection{Measurements}

\subsubsection{Roughness $[15],[20]$}

Surface roughness of treated and untreated fabrics was measured according to JIS-94 standard using surface roughness tester Model SE 1700. (Kosaka Laboratory Ltd.Japan).

\subsubsection{Antistatic property measurement [15], [20]}

Antistatic property measurement Static electricity of treated and untreated nylon fabrics was measured using electricity collect type FMX-003TM Electrostatic Field meter (Simco- Japan). The antistatic property measurements were carried out according to ASTM D 4238 .

Table 2: The Results of Fabrics Properties

\begin{tabular}{|c|c|c|c|c|c|c|}
\hline samples & $\begin{array}{l}\text { Rough- } \\
\text { ness } \mu \mathrm{m}\end{array}$ & $\begin{array}{l}\text { Thick- } \\
\text { ness } \\
(\mathrm{mm})\end{array}$ & $\begin{array}{l}\text { Weig } \\
\mathrm{ht} \\
\left(\mathrm{g} / \mathrm{m}^{2}\right)\end{array}$ & $\begin{array}{l}\text { Ant } \\
\text { Kv } \\
\text { af- } \\
\text { ter }\end{array}$ & $\begin{array}{l}\text { be- } \\
\text { fore }\end{array}$ & $\begin{array}{l}\text { Sewabil- } \\
\text { ity }\end{array}$ \\
\hline $\begin{array}{l}\text { Untreat- } \\
\text { ment A }\end{array}$ & 17.96 & 0.65 & $\begin{array}{l}2.099 \\
1\end{array}$ & 0 & 0 & 105 \\
\hline $\begin{array}{l}\text { Treatment } \\
\text { A } 5 \mathrm{gmll} \\
\mathrm{siO}_{2}\end{array}$ & 22.59 & 0.68 & 2.144 & $\begin{array}{l}0.0 \\
2\end{array}$ & 0 & 210 \\
\hline $\begin{array}{l}\text { Treatment } \\
\text { A } 10 \mathrm{gmll} \\
\mathrm{siO}_{2}\end{array}$ & 34.75 & 0.72 & $\begin{array}{l}2.186 \\
0\end{array}$ & $\begin{array}{l}0.0 \\
2\end{array}$ & 0 & 160 \\
\hline $\begin{array}{l}\text { Untreat- } \\
\text { ment B }\end{array}$ & 16.58 & 0.68 & $\begin{array}{l}1.513 \\
9\end{array}$ & $\begin{array}{l}0.0 \\
1\end{array}$ & 0 & 166 \\
\hline $\begin{array}{l}\text { Treatment } \\
\text { B } 5 \mathrm{gmll} \\
\mathrm{siO}_{2}\end{array}$ & 20.56 & 0.78 & $\begin{array}{l}2.351 \\
6\end{array}$ & $\begin{array}{l}0.0 \\
3\end{array}$ & 0 & 216 \\
\hline $\begin{array}{l}\text { Treatment } \\
\mathrm{B} 10 \mathrm{gmll} \\
\mathrm{siO}_{2}\end{array}$ & 30.28 & 0.81 & $\begin{array}{l}2.378 \\
3\end{array}$ & $\begin{array}{l}0.0 \\
3\end{array}$ & 0 & 175 \\
\hline
\end{tabular}

\subsubsection{UPF measurement [15], [20]}

Standard practice for preparation of textiles prior to ultraviolet (UV) transmission testing spectrophotometer for treated and untreated nylon fabrics measurements were carried out according to ASTM D 6544-12.

\subsubsection{Weight. [15], [20]}

Weight of treated and untreated nylon fabrics was measured using the weight measurements were carried out according to ASTM Standards. D1910-64 (1970).

\subsubsection{Thickness. [15], [20]}

Thickness of treated and untreated nylon fabrics was measured using the thickness measurements were carried out according to ISO 5084 .

\subsubsection{Sewability. [22]}

Using the sewability tester (based on US patent 3979951, 1976), a device used in many studies on the needle penetration force. This equipment simulates a sewing machine by penetrating the tested fabric with an unthreaded needle, at a rate of 100 penetrations per min., with needle count $18 \backslash 110$.

\subsubsection{Scanning electron microscope (SEM). [15], [20]}

The untreated and treated ultrasonic nylon fabrics were examined using a SEM Model Philips XL 30 with an EDX Unit attached, with accelerating voltage of $30 \mathrm{kV}$ and magnification between 10 and 400.000. All the samples were coated with gold before SEM testing.

All tests were carried out in National Institute for Standards after the samples were conditioned under standard atmospheric conditions(temperature $20 \pm 2{ }^{\circ} \mathrm{C}, 65 \pm 2 \%$ (relative humidity), according to standard ISO 139:1973. An exploratory data analysis containing central tendency and dispersion statistics was performed with the purpose of identifying outliers, normal behavior of the measured properties and also the homogeneity of variances. Then, univariate analysis of variance by using ANOVA procedure.

\section{Results and discussion}

In this study, surface treatments of nylon knitted fabrics $A \& B$ with using nano silicon dioxide $\left(\mathrm{SiO}_{2}\right)$ concentration $5 \& 10 \mathrm{gmll}$ are carried out to improve some of their properties such as antistatic charge, roughness, sewability,weight, thickness surface and UPF(ultraviolet protection factor). The obtained results will surely help to identify the design criteria for clothing so as to produce high quality garments, and the average value of fabrics are given in Table2.

\subsection{Scanning electron microscope (SEM)}

Changes of the surface morphology of Nylon fibers after treatment with Nano Silicon dioxide ( $\mathrm{sio}_{2}$ ). Were investigated using SEM as shown in figure 1. The SEM analysis of surface morphology reveals changes which occur on the surface of nylon fibers as a result of modification with Nano Silicon dioxide $\left(\mathrm{sio}_{2}\right)$. The treatment make then cover and penetration the treated nylon fabric, the more effect happens with increasing the concentration Nano Silicon dioxide $\left(\mathrm{sio}_{2}\right) 5 \& 10 \mathrm{gml}$. This result illustrates the effect in properties of treated nylon fabrics as compared with untreated one.

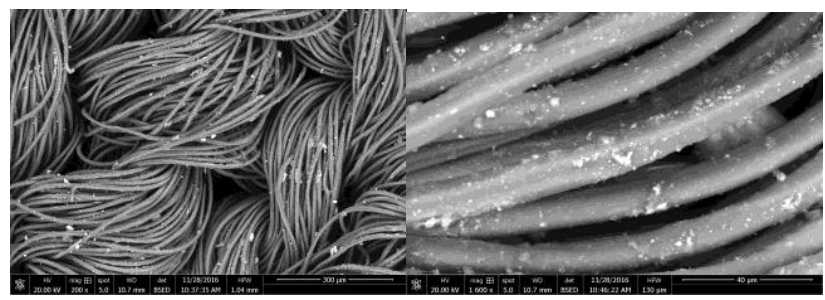

Treated nylon A 5 gm\l sio $_{2}$

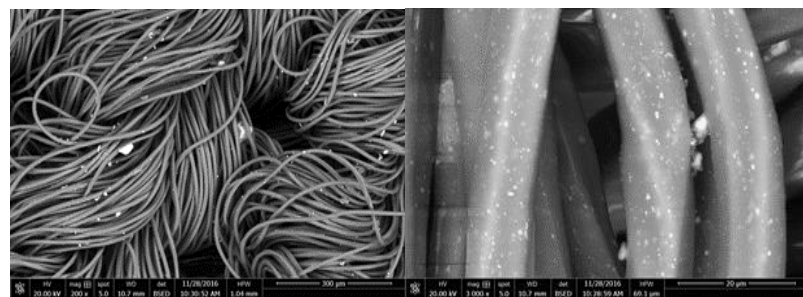

Treated nylon A 10 gmll sio $_{2}$ 


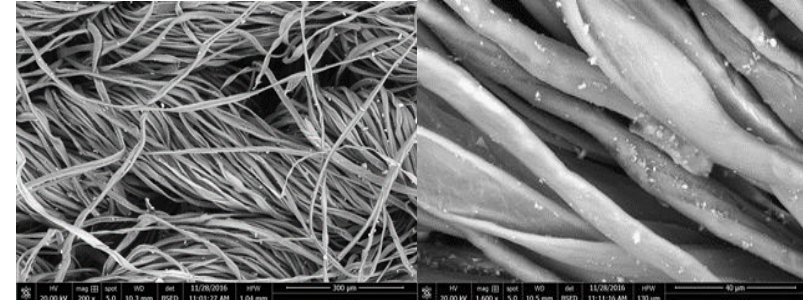

Treated nylon B 5 gmll $\mathrm{sio}_{2}$

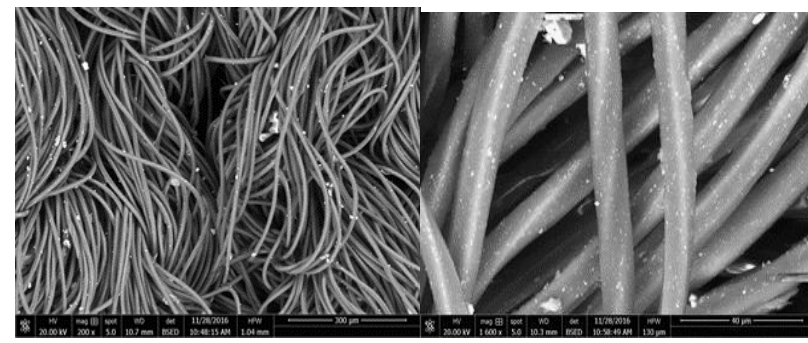

Treated nylon B $10 \mathrm{gmll} \mathrm{\textrm {sio } _ { 2 }}$

Fig .1: Surface Morphology of Untreated and Treated Nylon Fibers with Nano Silicon Dioxide $\left(\mathrm{SiO}_{2}\right)$.

\subsection{Antistatic charge KV}

Figure 2 and table 2 show the antistatic charge of untreated and treated Nylon fabrics with nano silicon dioxide. It is found that the treatment reduces the antistatic charge of treated fabrics than untreated ones. This enhancement may be attributed to improved moisture regain of the treated fabrics. The increase of moisture regain for the treated fabrics could be attributed to the opening of the fiber structure with the aid of $\mathrm{SiO}_{2}$ nanoparticle, which allowed more water vapor molecules to penetrate the fiber structure. Improving antistatic property all samples after treatment when compare the sample after and before treatment.

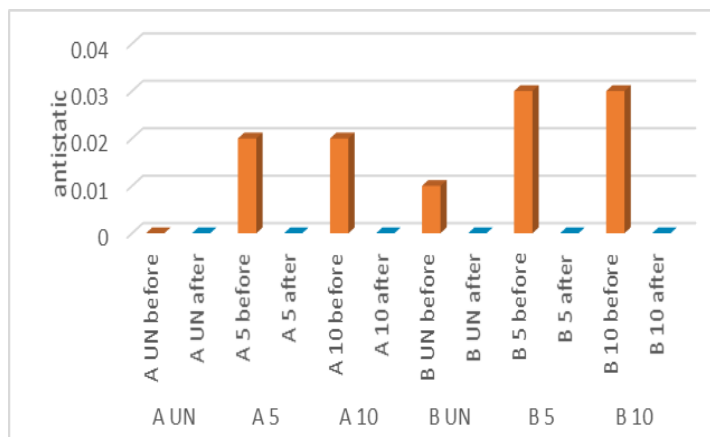

Fig. 2: The Relation between Antistatic Charge and Concentration of Nano Silicon Dioxide $\left(\mathrm{Sio}_{2}\right)$.

\subsection{Roughness property}

The treated fabrics are tested for roughness. Results of this analysis are tabulated in figure 3 . The results show that, there are increases in the treated fabrics. In the roughness data show some change for treated fabrics than untreated one. Treated Nylon A\&B fabrics with $10 \mathrm{gmll}$ nano silicon dioxide improve the roughness when compare treated Nylon A\&B fabrics with $5 \mathrm{gmll}$ nano silicon dioxide. This may be attributed to the treatment make then cover and penetration the treated nylon fabric, the more effect happens with increasing the concentration Nano Silicon dioxide ( sio2 $\left._{2}\right) 5 \& 10 \mathrm{gmll}$. figure 1.

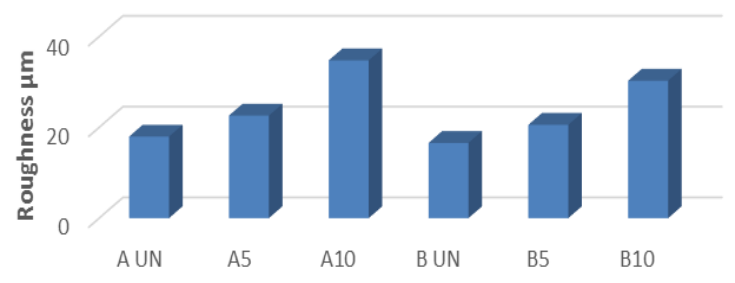

Fig. 3: The Relation between Roughness Property and Concentration of Nano Silicon Dioxide $\left(\mathrm{Sio}_{2}\right)$.

\subsection{Surface thickness}

Figure 4 shows surface thickness of untreated and treated fabrics. Surface thickness does not themselves have any great impact upon the tailoring performance of a fabric but are useful indicators of any change or variation in fabric handle [9]. The treatment improved surface thickness samples values which indicating the finish on the fabric is unstable.

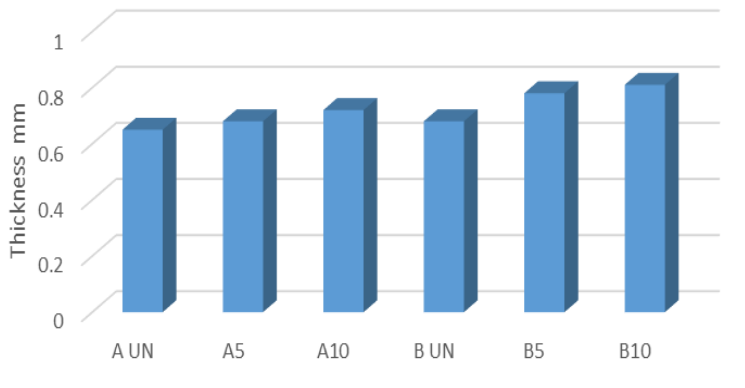

Fig. 4: The Relation between Surface Thickness and Concentration of Nano Silicon Dioxide $\left(\mathrm{Sio}_{2}\right)$.

\subsection{Weight}

Figure 5 shows weight of untreated and treated fabrics. The results show that, there are increases in the treated fabrics. In the weight data show change for treated fabrics than untreated one. Treated Nylon A\&B fabrics with $10 \mathrm{gmll}$ nano silicon dioxide improve the weight when compare treated Nylon A\&B fabrics with $5 \mathrm{gml}$ nano silicon dioxide. This may be attributed to the treatment make then cover and penetration the treated nylon fabric, the more effect happens with increasing the concentration Nano Silicon dioxide ( $\left.\operatorname{sio}_{2}\right) 5 \& 10 \mathrm{gmll}$. figure 1. 


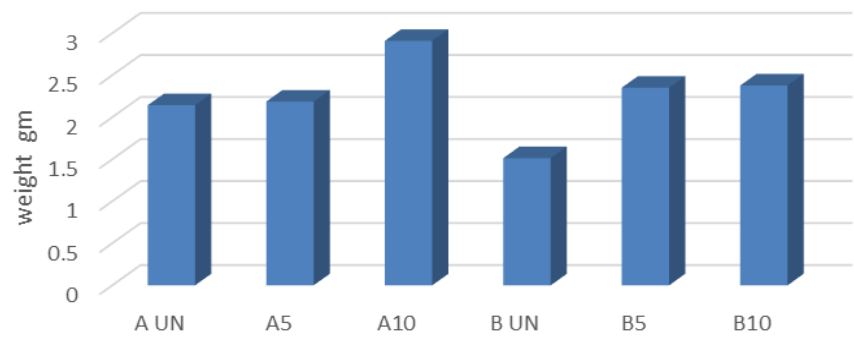

Fig. 5: The Relation between Weight and Concentration of Nano Silicon Dioxide $\left(\mathrm{Sio}_{2}\right)$.

Table 3: The Results of UPF Measurement. Where: $\mathrm{L}=$ Wave Length. DT = Diffuse Transmittance.

\begin{tabular}{|c|c|c|c|c|c|c|c|c|c|c|c|}
\hline \multirow{2}{*}{$\frac{\text { A-UN }}{\text { W L (nm) }}$} & \multicolumn{3}{|c|}{ A-5 } & A-10 & \multicolumn{2}{|c|}{ B-Un } & \multicolumn{3}{|c|}{ B-5 } & \multicolumn{2}{|l|}{ B-10 } \\
\hline & D T \% & $\mathrm{W}$ L (nm) & D T \% & W L (nm) & D T \% & W L (nm) & D T \% & W L (nm) & D T \% & W L (nm) & D T \% \\
\hline 400 & 15.719 & 400 & 11.417 & 400 & 11.116 & 400 & 12.458 & 400 & 9.035 & 400 & 8.540 \\
\hline 395 & 14.878 & 395 & 10.614 & 395 & 10.308 & 395 & 11.811 & 395 & 8.470 & 395 & 7.958 \\
\hline 390 & 13.734 & 390 & 9.500 & 390 & 9.232 & 390 & 11.089 & 390 & 7.770 & 390 & 7.287 \\
\hline 385 & 12.024 & 385 & 7.968 & 385 & 7.729 & 385 & 10.192 & 385 & 6.990 & 385 & 6.444 \\
\hline 380 & 9.484 & 380 & 5.753 & 380 & 5.603 & 380 & 9.002 & 380 & 5.909 & 380 & 5.364 \\
\hline 375 & 6.248 & 375 & 3.217 & 375 & 3.138 & 375 & 7.353 & 375 & 4.467 & 375 & 3.955 \\
\hline 370 & 3.378 & 370 & 1.379 & 370 & 1.311 & 370 & 5.389 & 370 & 2.976 & 370 & 2.542 \\
\hline 365 & 1.812 & 365 & 0.567 & 365 & 0.528 & 365 & 3.805 & 365 & 1.907 & 365 & 1.578 \\
\hline 360 & 1.132 & 360 & 0.298 & 360 & 0.261 & 360 & 2.792 & 360 & 1.325 & 360 & 1.084 \\
\hline 355 & 0.855 & 355 & 0.196 & 355 & 0.171 & 355 & 2.271 & 355 & 1.055 & 355 & 0.859 \\
\hline 350 & 0.728 & 350 & 0.156 & 350 & 0.130 & 350 & 1.968 & 350 & 0.916 & 350 & 0.757 \\
\hline 345 & 0.609 & 345 & 0.144 & 345 & 0.111 & 345 & 1.828 & 345 & 0.857 & 345 & 0.718 \\
\hline 340 & 0.575 & 340 & 0.129 & 340 & 0.096 & 340 & 1.680 & 340 & 0.805 & 340 & 0.651 \\
\hline 335 & 0.549 & 335 & 0.121 & 335 & 0.083 & 335 & 1.591 & 335 & 0.754 & 335 & 0.629 \\
\hline 330 & 0.550 & 330 & 0.122 & 330 & 0.088 & 330 & 1.520 & 330 & 0.725 & 330 & 0.601 \\
\hline 325 & 0.541 & 325 & 0.120 & 325 & 0.088 & 325 & 1.520 & 325 & 0.710 & 325 & 0.579 \\
\hline 320 & 0.543 & 320 & 0.123 & 320 & 0.090 & 320 & 1.509 & 320 & 0.720 & 320 & 0.588 \\
\hline 315 & 0.554 & 315 & 0.122 & 315 & 0.085 & 315 & 1.453 & 315 & 0.678 & 315 & 0.562 \\
\hline 310 & 0.553 & 310 & 0.127 & 310 & 0.094 & 310 & 1.389 & 310 & 0.667 & 310 & 0.544 \\
\hline 305 & 0.556 & 305 & 0.127 & 305 & 0.093 & 305 & 1.371 & 305 & 0.656 & 305 & 0.550 \\
\hline 300 & 0.572 & 300 & 0.130 & 300 & 0.098 & 300 & 1.371 & 300 & 0.682 & 300 & 0.559 \\
\hline 295 & 0.571 & 295 & 0.142 & 295 & 0.102 & 295 & 1.379 & 295 & 0.692 & 295 & 0.568 \\
\hline 290 & 0.568 & 290 & 0.148 & 290 & 0.110 & 290 & 1.338 & 290 & 0.713 & 290 & 0.603 \\
\hline
\end{tabular}

\subsection{UPF measurement}

The measured transmittance data for the untreated and treated fabrics. showFigures6\&7can also be converted to UPF values: The increase in UPF offered by the treated fabrics additive is apparent from Table 3. The same advantage applies to the total Blocking $(100 \%$-T\%) for either UVA (315 nm - $400 \mathrm{~nm})$ or UVB (280 nm $315 \mathrm{~nm}$ ). Treated Nylon A\&B fabrics with $10 \mathrm{gmll}$ nano silicon dioxide improved sun protection when compare treated Nylon A\&B fabrics with $5 \mathrm{gmll}$ nano silicon dioxide. Emission spectrum in Figures $6 \& 7$ was isolated by the measured difference between the treated and untreated fabrics. The increased absorption at UV wavelengths is also evident. The relative strengths of both the absorption and the emission spectra are proportional to the concentration of the Treated Nylon A\&B fabrics with10 gmll nano silicon dioxide. Quantitative analysis is possible by devising a calibration curve using a sample set of known10 gmll concentration. The application Is uniquely supported by the design of the UV $-1000 \mathrm{~F}$ due to its use of polychromatic illumination, diffuse Transmittance geometry and spectral range of $250 \mathrm{~nm}$ to $450 \mathrm{~nm}$. Optical brightening agents are often applied to enhance the whiteness of textiles by inducing fluorescence by UV excitation and visible blue emission. $10 \mathrm{gmll}$ concentration has the added benefit of increasing the UV absorption and hence a textile's sun protective ability.

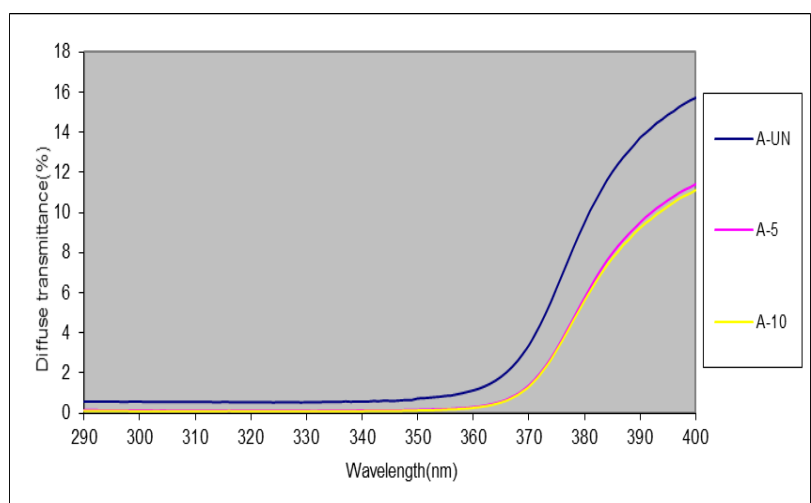

Fig. 6: The Relation between UPF Measurements and Concentration of Nano Silicon Dioxide (Sio2) Nylon.

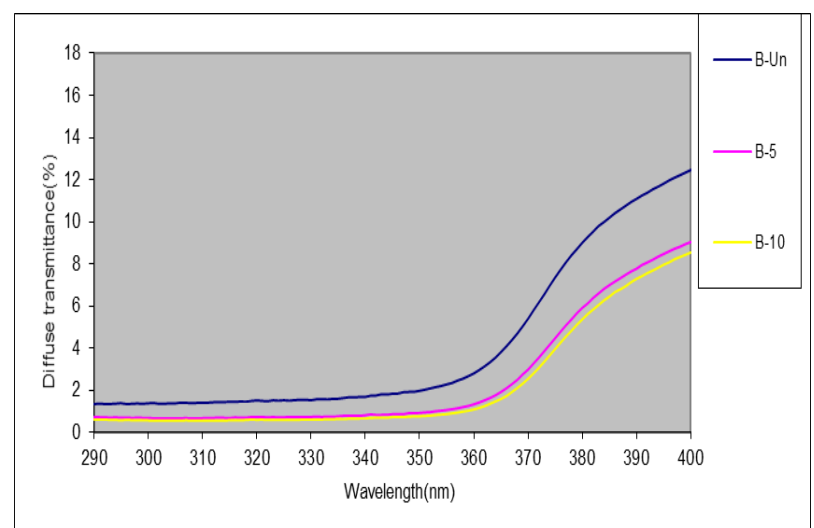

Fig. 7: The Relation between UPF Measurements and Concentration of Nano Silicon Dioxide $\left(\mathrm{Sio}_{2}\right)$ Nylon. 


\subsection{Sewability (sewing needle penetrations force)}

The figure 8 , illustrated the sewing needle Penetration force which have been calculated, the untreated and treated fabrics. It can see that needle penetrations force increase for treated fabrics than others. Sewing needle penetrations force increase for samples $\mathrm{A}_{5}$ and $\mathrm{B}_{5}$ (treated with $5 \mathrm{~g} / \mathrm{SIO}_{2}$ ), but Penetrations force decrease for samples $A_{10}$ and $B_{10}$ (treated with $10 \mathrm{~g} / 1 \mathrm{SIO}_{2}$ ). The results show that treatment improves sewing needle penetration force property.

Table 4: One-Way ANOVA of the Untreated and Treated Fabrics Properties

\begin{tabular}{|c|c|c|c|c|c|}
\hline property & Source of Variation & $\begin{array}{l}d \\
f\end{array}$ & $\mathrm{~F}$ & $\begin{array}{l}\mathrm{P}- \\
\text { value }\end{array}$ & $\begin{array}{l}\mathrm{F} \\
\text { critical }\end{array}$ \\
\hline $\begin{array}{l}\text { Weight } \\
(\mathrm{g} / \mathrm{m} 2)\end{array}$ & $\begin{array}{l}\text { AUN,Bun,A5,B5,A1 } \\
0, \mathrm{~B} 10\end{array}$ & 5 & $\begin{array}{l}5390397 . \\
746\end{array}$ & $\begin{array}{l}1.14 \mathrm{E}- \\
37\end{array}$ & $\begin{array}{l}3.1058 \\
75\end{array}$ \\
\hline $\begin{array}{l}\text { Thick- } \\
\text { ness } \\
(\mathrm{mm})\end{array}$ & $\begin{array}{l}\text { AUN,Bun,A5,B5,A1 } \\
0, \mathrm{~B} 10\end{array}$ & 5 & $\begin{array}{l}338.2666 \\
667\end{array}$ & $\begin{array}{l}1.78 \mathrm{E}- \\
12\end{array}$ & $\begin{array}{l}3.1058 \\
75\end{array}$ \\
\hline $\begin{array}{l}\text { antistatic } \\
\text { charge } \\
\mathrm{Kv}\end{array}$ & $\begin{array}{l}\text { AUN,Bun,A5,B5,A1 } \\
0, \mathrm{~B} 10\end{array}$ & 5 & 65535 & $\begin{array}{l}1.82 \mathrm{E}- \\
30\end{array}$ & $\begin{array}{l}2.0666 \\
08\end{array}$ \\
\hline $\begin{array}{l}\text { Rough- } \\
\text { ness } \\
\mu \mathrm{m}\end{array}$ & $\begin{array}{l}\text { AUN,Bun,A5,B5,A1 } \\
0, \mathrm{~B} 10\end{array}$ & 5 & $\begin{array}{l}3513444 . \\
6\end{array}$ & $\begin{array}{l}1.49 \mathrm{E}- \\
36\end{array}$ & $\begin{array}{l}3.1058 \\
75\end{array}$ \\
\hline $\begin{array}{l}\text { Sewabil- } \\
\text { ity } \\
\text { (Sewing } \\
\text { needle } \\
\text { penetra- } \\
\text { tions } \\
\text { force) }\end{array}$ & $\begin{array}{l}\text { AUN,Bun,A5,B5,A1 } \\
0, \mathrm{~B} 10\end{array}$ & 5 & $\begin{array}{l}10850.02 \\
5\end{array}$ & $\begin{array}{l}1.71 \mathrm{E}- \\
21\end{array}$ & $\begin{array}{l}3.1058 \\
75\end{array}$ \\
\hline UPF & $\begin{array}{l}\text { AUN,Bun,A5,B5,A1 } \\
0, \mathrm{~B} 10\end{array}$ & 5 & $\begin{array}{l}0.176699 \\
149 \\
\end{array}$ & $\begin{array}{l}0.9678 \\
67 \\
\end{array}$ & $\begin{array}{l}2.7728 \\
53\end{array}$ \\
\hline
\end{tabular}

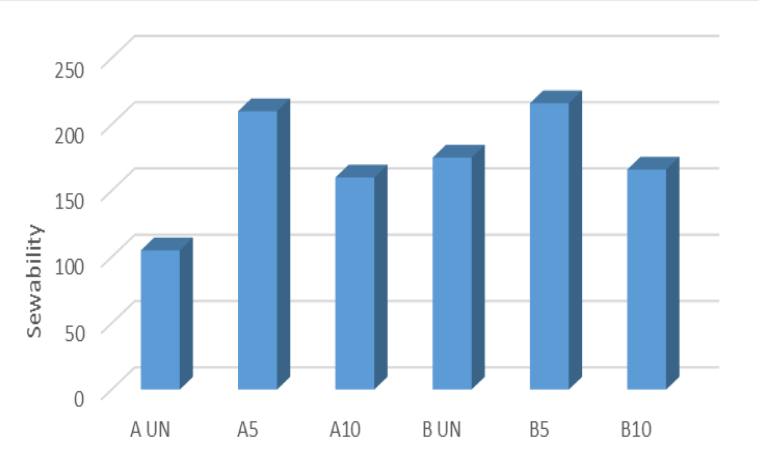

Fig. 8: The Relation between Sewing Needle Penetrations Force and Concentration of Nano Silicon Dioxide $\left(\mathrm{SiO}_{2}\right)$.

Statically evaluation

The above-mentioned results are confirmed by analysis of variance (ANOVA), and the result is significant influence of the untreated and treated fabrics properties.

Note: ANOVA: analysis of variance.

The ANOVA confirmed that there are different properties between untreated and treated fabrics proved the significant difference among all the groups. By considering all the above cases, the results of the ANOVA are listed in Table 4, which analyses the effect of groups of fabrics samples with respect to Weight, Thickness, antistatic charge, Roughness, Sewing needle penetrations force, UPF.

Proves that the changes in properties of fabrics results is highly significant differences.

Show table 4, there are significant differences between weight of fabrics $\mathrm{A}_{\mathrm{uN}}, \mathrm{B}_{\mathrm{un}}, \mathrm{A}_{5}, \mathrm{~B}_{5}, \mathrm{~A}_{10}, \mathrm{~B}_{10}$ indication this $\mathrm{P}$-value $=1.14 \mathrm{E}-37$, where fabric $A_{10}$ is highest weight and then $B_{10}$ and then $B_{5}$ and Asfinally Aun and Bun. Treated Nylon A\&B fabrics with $10 \mathrm{gmll}$ nano silicon dioxide improve the weight when compare treated Nylon A\&B fabrics with $5 \mathrm{gm} \backslash \mathrm{l}$ nano silicon dioxide.

There are significant differences between thickness of fabrics $\mathrm{A}_{\mathrm{uN}}, \mathrm{B}_{\mathrm{un}}, \mathrm{A}_{5}, \mathrm{~B}_{5}, \mathrm{~A}_{10}, \mathrm{~B}_{10}$ indication this $\mathrm{P}$-value $=1.78 \mathrm{E}-12$, where fabric $\mathrm{A}_{10}$ is highest weight and then $\mathrm{B}_{10}$ and then $\mathrm{B}_{5}$ and $\mathrm{A}_{5}$ finally $A_{u n}$ and $B_{u n}$. Treated Nylon A\&B fabrics with 10 gmll nano silicon dioxide improve the weight when compare treated Nylon A\&B fabrics with 5 gm $\backslash$ nano silicon dioxide.

There are significant differences between antistatic charge of fabrics $\mathrm{A}_{\mathrm{uN}}, \mathrm{B}_{\mathrm{un}}, \mathrm{A}_{5}, \mathrm{~B}_{5}, \mathrm{~A}_{10}, \mathrm{~B}_{10}$ indication this $\mathrm{P}$-value $=1.82 \mathrm{E}-30$, where treated fabrics Treated with5 gmll and $10 \mathrm{gmll}$ nano silicon dioxide improve the antistatic charge when compare untreated Nylon fabrics.

There are significant differences between Roughness of fabrics $\mathrm{A}_{\mathrm{uN}}, \mathrm{B}_{\mathrm{un}}, \mathrm{A}_{5}, \mathrm{~B}_{5}, \mathrm{~A}_{10}, \mathrm{~B}_{10}$ indication this $\mathrm{P}$-value $=1.49 \mathrm{E}-36$, where treated fabrics Treated with5 gmll and $10 \mathrm{gmll}$ nano silicon dioxide improve the Roughness of fabrics when compare untreated Nylon fabrics.

There are significant differences between Sewability(Sewing needle penetrations force) of fabrics $\mathrm{A}_{\mathrm{uN}}, \mathrm{B}_{\mathrm{un}}, \mathrm{A}_{5}, \mathrm{~B}_{5}, \mathrm{~A}_{10}, \mathrm{~B}_{10}$ indication this $\mathrm{P}$-value $=1.71 \mathrm{E}-21$, where treated fabrics Treated with5 gml and $10 \mathrm{gmll}$ nano silicon dioxide improve the Sewability(Sewing needle penetrations force)of fabrics when compare untreated $\mathrm{Ny}$ lon fabrics.

There are significant differences between UPF(ultraviolet protection factor) of fabrics $\mathrm{A}_{\mathrm{UN}}, \mathrm{B}_{\mathrm{un}}, \mathrm{A}_{5}, \mathrm{~B}_{5}, \mathrm{~A}_{10}, \mathrm{~B}_{10}$ indication this $\mathrm{P}$ value $=0.967867$, where treated fabrics Treated with $5 \mathrm{gmll}$ and 10 gmVl nano silicon dioxide improve the UPF of fabrics when compare untreated Nylon fabrics.

The ANOVA confirmed that there are the treatments with nano silicon dioxide significant improve some of their properties than untreated fabrics.

\section{Conclusion}

The treatments with nano silicon dioxide significant improve some of their properties such as antistatic charge, roughness, sew ability (Sewing needle penetrations force), weight, thickness surface and UPF(ultraviolet protection factor) than untreated fabrics . The obtained results will surely help to identify the design criteria for clothing so as to produce high quality garments.

Treated Nylon A\&B fabrics with 10 gmll nano silicon dioxide improve the their properties when compare treated Nylon A\&B fabrics with $5 \mathrm{gmll}$ nano silicon dioxide, but Sewing needle penetrations force increase for samples $A_{5}$ and $B_{5}$ (treated with $5 \mathrm{~g} / \mathrm{l}$ $\mathrm{SIO}_{2}$ ), but Penetrations force decrease for samples $\mathrm{A}_{10}$ and $\mathrm{B}_{10}$ (treated with $10 \mathrm{~g} / \mathrm{l} \mathrm{SIO} 2$ ).

\section{References}

[1] N. Duran, P.D. Marcato, G. De Souza, Antibacterial effect of silver nanoparticlesby fungal process on textile fabrics and their effluent treatment. J Biomed Nanotechnology; 3(2007), 203-208. https://www.researchgate.net/publication/233512276. https://doi.org/10.1166/jbn.2007.022.

[2] Y. Wong, C. Yuen, M. Leung;. Selected applications of Nanotechnology textiles, Autex Res J, 6, (2006), p. 1-8. http://yadda.icm.edu.pl/yadda/element/bwmeta1.element.baztechb1b1274f-d779-4a08-87c8-94750dd28d5f

[3] A. Yadav, V. Prasad, A. Kathe, Functional finishing in cotton fabrics using zincoxide nanoparticles, Bull Mater, Sci, 29, (2006): 641-645. https://link.springer.com/article/10.1007/s12034-0060017-y. https://doi.org/10.1007/s12034-006-0017-y.

[4] Y. Zhang, Li Yu, S. Ke, TiO2/SiO2 hybrid nanomaterials: Synthesis and variable UV-blocking properties. J Sol-Gel Sci Techno, 58, (2011): 326-329. http://www.academia.edu/1127162/TiO_2_SiO_2 hybrid_nanomat erials_synthesis_and_variable_UV-blocking_properties. https://doi.org/10.1007/s10971-010-2395-2.

[5] B. Mahltig, F. Audenaert, \& H.Bottcher, Hydrophobic Silica sol coatings on textiles - The influence of solventand sol concentration. Journal of Sol-Gel Science and Technology, 34(2005), 103-109. http://www.academia.edu/22032550/Hydrophobic Silica Sol Coatings on Textiles the Influence of Solvent and So Concentration. https://doi.org/10.1007/s10971-005-1321-5.

[6] M. Smole, K. Stakne, M. Bele, J.Jamnik, S. Hribernik, \& V.Ribitsch, "Nanocoatings for textile" the 3rdinternational textile 
clothing \& design conference Dubrovnik, Croatia, 8-11 October(2006).

[7] A. Ghosh, "Coating on viscose - Poor wet strength of viscose can be improved by the application of chemical finishes like water repellent and soil release finishes" International Journal of Engineering \& Technology, 11, (2011), 78-85. http://citeseerx.ist.psu.edu/viewdoc/download?doi=10.1.1.418.8661 $\&$ rep $=$ rep $1 \&$ type $=$ pdf

[8] D. Judd, \& G. Wyszecki, "Color in business, science, and industry" NY, USA: Wiley (1975).https://www.amazon.com/Business-Science-IndustryApplied-Optics/dp/0471452122

[9] T. Hussaina, S. Ahmedb, and A. Qayumb, "Effect of different softeners and sanforising treatment on pilling performance of polyester /viscose blended fabrics" Society of Dyers and Colourists, Color. Technol, ， (2008)124, 375-378-375. http://www.academia.edu/368488/Effect of Different Softeners and Sanforising Treatment on Pilling Performance of Polyester Viscose Blended Fabrics

[10] H.Eberle, and others, Clothing technology from fiber to fash-ion, Nourney, Vollmer, Gmbh\& co., (2016). http://www.europalehrmittel.de/downloads-leseproben/62218-6/517.pdf/

[11] http://www.nikonsmallworld.com

[12] P.Roshan, functional finishes for textiles, improving comfort, performance and protection,Elsevier,October(2014).

[13] P.Shilpa, V. Verma, and M. Gupta, Growing Importance of Cotton Blends in Apparel Market, J.Tex.Assoc.Vol.67 (5), (2007), p. 201 210.

[14] K.Gotlih, , and D. Lojen, proc.78 the world conference of the textile institute in a associations with the 5th textile symposium of seven and sepve, Greece, (1997),pp.133-147.

[15] Amrican Society for testing and material. Annualbook of ASTM standards.Textiles-yarns, Fabricsand General test methods, standard specification for tensile testing for Textiles, ASTMDes-ignation: D1908-89, ASTM, Easton, PA, 1990.

[16] C.Helder, M. Ana, and 1. Joao, The journal of the textile institute, vol. 100, No. 4, May, (2009), 319-329. http://www.tandfonline.com/doi/abs/10.1080/00405000701806839? journalCode=tjti20. https://doi.org/10.1080/00405000701806839.

[17] M. Abdel Megeid, M. Al-bakry and M. Ezzat, The influence of stitch length of weft knitted fabrics on the sewability, Journal of American Science, 7(8), (2011). http://docplayer.net/24878691Key-words-stitch-length-weft-knitted-fabric-sewability-abrasionresistance-air-permeability.html

[18] S. Kathirvelu , L.Souza , B. Dhurai , Nanotechnology Appli-cations in Textiles,Indian journal of science\& technology ,Vol.1, Issue 5, October 2008 http://www.indjst.org/index.php/indjst/article/view/29361

[19] E.Peter, 1.Kathryn, Textiles and the skin, walter wigger albertikarger medical and scientific publishers, (2003).

[20] E.gennady, 1. zaikov, analysis and performance of engineering materials, key research and development, CRC press, Aug, (2015).

[21] F.Ebrahim and O. Allam, "Effect of Nano Silica on Garment Appearance" J. Basic. Appl. Sci. Res., (2012) 2(6), 5855-5862. http://textroad.com/pdf/JBASR/J.\%20Basic.\%20Appl.\%20Sci.\%20 Res.,\%202(6)5855-5862,\%202012.pdf

[22] Annual book of ASTM standards, part 23. Philadelphia, (1982).

[23] J.E.Booth, Principles of Textile Testing, vol. 6, (1968), pp.282.

[24] The L+M Sewability Tester BS EN ISO 9002 certificate no.2739. 